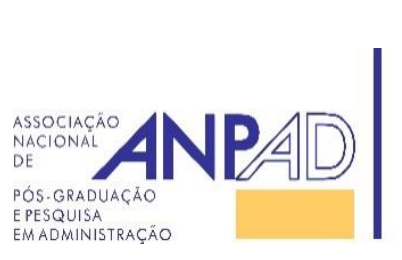

Available online at http://www.anpad.org.br/bar

BAR, Rio de Janeiro, v. 14, n. 4, art. 4, e170050, 2017

http://dx.doi.org/10.1590/1807-7692bar2017170050

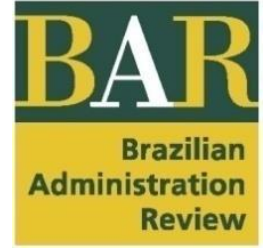

\title{
Drawing the Triangle: How Coaches Manage Ambiguities Inherited in Executive Coaching
}

Ana Pliopas ${ }^{1}$

Fundação Getulio Vargas, Escola de Administração de Empresas de São Paulo ${ }^{1}$

Received 30 April 2017; received in revised form 25 October 2017; accepted 14 November 2017; first published online 13 December 2017.

Editor's note. Wilson Aparecido da Costa Amorim served as Action Editor for this article. 


\begin{abstract}
Executive coaching is a common leadership development intervention whose complexity is underestimated. The triangular relationships between coachee, coach, and organization give rise to conflicting interests (FatienDiochon, 2012). This study examines how coaches perceive triangular relationships and reflect on conflicts of interest and ethical issues. During semi-structured interviews, nine coaches drew their interpretations of how triangular relationships unfold in executive coaching processes. Coaches' explanations were categorized into three groups. There are coaches who understand executive coaching as a harmonious and congruent process, called naïve; some coaches rely on the coaching process to deal with conflicts of interest, and we called them procedural. Other coaches are skeptical when dealing with conflict of interests in triangular relationships, and were called suspicious. In order to support coaches facing ethical dilemmas that may be present in triangular relationships in the executive coaching process, the ethics of the profession perspective developed for the educational sector by Shapiro and Stefkovich (2016) was adapted and integrated into Carroll and Shaw's (2013) ethical maturity perspective. This adapted model offers coaches an integrative and dynamic view to foster their development and ethical maturity.
\end{abstract}

Key words: executive coaching; triangular relationship; ethical maturity; social constructionism. 


\section{Introduction}

Executive coaching is a leadership development intervention frequently found in contemporary organizations (Sherman \& Freas, 2004) that has gained considerable popularity since the 1980s (Feldman \& Lankau, 2005; Grant, 2014; Stelter, 2009; Western, 2012). The International Coach Federation (ICF, 2016a) found that coaching grosses USD 2.3 billion annual business revenues worldwide, with 13,895 registered coaches.

There are multiple approaches to executive coaching, and different authors have inspired our definition: executive coaching is an organizational development process (de Haan, Duckworth, Birch, \& Jones, 2013) conducted by a professional coach (Bozer, Sarros, \& Santora, 2014), consisting of individual interactions (Reissner, 2008; Reissner \& Toit, 2011), and aiming at providing meaningmaking (Reissner \& Toit, 2011), and, from this, a change in executives' attitude (Bluckert, 2006) and/or action (Joo, 2005).

In executive coaching, there are at least three stakeholders: the person receiving coaching, or coachee; the person external to the organization hired to conduct the coaching process, the coach; and those representing the organization, typically the coachee's manager and a Human Resources professional. Other people from the organization may also be involved, like the coachee's peers and subordinates, or even members of the board of directors.

In an ideal world, organizational and executive developmental goals are congruent, and the coach, by supporting the coachee's development, supports better performance and thus achieves organizational objectives. But this is not always the case, as organizations may have intentions quite different from the expectations of the coachee (Skinner, 2012). For example, a coachee may be interested in relating better to his/her manager, while the manager hopes the coachee will relate better to his/her peers. There also may be different agendas in executive coaching processes (Louis \& Fatien-Diochon, 2014): organizations may hire a coach as a last resource before firing an executive, but the decision of dismissal has already been made. The main stakeholders in executive coaching (coachee, coach, and organization) form a triangular relationship (Louis \& Fatien-Diochon, 2014). Between the stakeholders there might be different objectives, agendas, and conflicts of interests, and when objectives are not congruent, decisions must be made about what is right or wrong, and issues of ethics and morality may emerge.

Ethics inform individuals in practical aspects so they become virtuous and good (London, 2001) and "ethos means customs or usages belonging to one group as distinguished from another" (Shapiro \& Stefkovich, 2016, p. 10). Moral and ethical concerns are not central in an organizational context (Ghoshal, 2005) and executive coaching, as an organizational development intervention, is no exception: ethical concerns are most of the time restricted to coaches agreeing to a code of ethics (Carroll \& Shaw, 2013; Fatien-Diochon \& Nizet, 2015).

Formal coaching codes of ethics are necessary but not sufficient in supporting coaches faced with ethical dilemmas and deciding the best action (Gray, 2011). Aiming to provide structure to ethical decision making in coaching, Duffy and Passmore (2010) proposed a sequential, yet non-linear, model for coaches. Carroll and Shaw (2013) proposed a more comprehensive reflective perspective for executive coaches to make decisions, learn from ethical dilemmas, and live with their decisions, continuously developing ethical maturity. Ethical maturity is not a stage to be reached, but a path of continuous development. Duffy and Passmore (2010) and Carroll and Shaw (2013) agree that the first step to deal with an ethical dilemma is to be aware of it.

The coach, who is responsible for conducting the coaching process (Stern, 2004), may give an impression of being neutral, as argued by some authors like Rocha-Pinto and Snaiderman (2011); other authors, though, reinforce the idea that executive coaches are not impartial, exempt (Critchley, 2010), or detached from issues in executive coaching processes (Louis \& Fatien-Diochon, 2014; Skinner, 2012). Instead, coaches engage with coachees in a relational process, where meanings are created (Reissner \& Toit, 2011). Coachee and coach influence one another (Critchley, 2010) and are influenced 
by the wider context of the organization (Reissner \& Toit, 2011). In short: coaches are not neutral and take part in relational processes that they also conduct; in such processes, there may be conflicts of interests and ethical dilemmas.

Since coaches are responsible for conducting executive coaching processes (Stern, 2004), and in such processes there are triangular relationships prone to ethical dilemmas (Fatien-Diochon, 2012; Fatien-Diochon \& Nizet, 2015; Louis \& Fatien-Diochon, 2014); and the first step to a reflective perspective path to ethical maturity requires coaches to be aware of the existence of ethical dilemmas (Carroll \& Shaw, 2013; Duffy \& Passmore, 2010), a research gap exists: there is a need to further understand how coaches perceive triangular relationships in executive coaching and if and how they reflect on possible conflicts of interest in executive coaching. This study draws on the principles of social constructionism to address this problem.

Social constructionism is a theoretical movement concerned with the ways knowledge is historically located and inserted in cultural and values practices (Burr, 2015; Camargo-Borges \& Rasera, 2013). It also emphasizes that meanings and knowledge are created in relationships and dialogues (Cunliffe, 2008; Gergen, 2009; McNamee \& Hosking, 2012). From this view, the research objective is to expand the options of understanding the phenomenon (Camargo-Borges \& Rasera, 2013). This way, by understanding meanings executive coaches attribute to triangular relationships, one can expand the possibilities to understand executive coaching; pondering if and how coaches reflect on possible conflicts of interest in executive coaching, expands perspectives for coaching theorists and practitioners.

The research strategy employed here is a combination of semi-structured interviews and visual data methods, more specifically the participant-produced drawing technique (Kearney \& Hyle, 2004). Nine executive coaches were interviewed and invited to draw a representation of the relationships between the coachee, the organization, and the coach in executive coaching processes. The thematic analysis allows us to propose there are coaches who understand executive coaching as being a harmonious and congruent process (naïve coaches); among coaches who acknowledge different agendas may exist, there are coaches who perceive themselves as neutral and deal with conflict of interests in a prescriptive way (procedural coaches); and there are those who see themselves as part of the process, being influenced and influencing the system (suspicious coaches). Empirical material analyses suggest there is room for an integrative model that prompts coaches to reflect critically about ethical dilemmas. This study adapted a perspective from the ethics of the profession view proposed by Shapiro and Stefkovich (2016). Because of this, this paper contributes to the field by expanding understandings of triangular relationships in executive coaching, and offers an integrative perspective to prompt coaches to reflect critically.

\section{Theoretical Framework}

This section comprises three parts: social constructionism is the theoretical lens which informs the research as a whole; ethical coaching relates to ethics in general, and more specifically in executive coaching; and triangular relationships in executive coaching, the phenomenon studied in the research, are presented. The section finishes with an integration of the three theoretical perspectives, orienting the analyses of the empirical material.

\section{Social constructionism}

Social constructionism is concerned with understanding the processes by which people describe, explain, and account for the world in which they live, including themselves (Gergen, 1985). Traditions such as sociology, social philosophy, and sociology of knowledge have influenced social constructionism (Cunliffe, 2008), and its basic idea is "man constructs his own nature, or more simply, that man creates himself" (Berger \& Luckmann, 2002, p. 27, our translation). In other words, what is considered to be real is subject to people agreeing to such truth, which depends on interactions between 
people. Thus, the way meanings are constructed, or the building of accounts and the building of the world, orient people's actions (Hepburn \& Wiggins, 2005).

Gergen (2009) presents assumptions at play in the social constructionist perspective, among which two are most relevant to this research: the ways in which we describe and explain the world are outcomes of relationships; and reflection on our taken-for-granted worlds is vital for our future wellbeing.

If we assume that the construction of meanings occurs in relational processes, understandings about the world are then reached by coordination between people: negotiations, agreements, and compared visions, for example. In social constructionism, relationships precede everything that is intelligible, and nothing exists as a comprehensible world of objects and people until there are relationships. If we seek certainty, something to count on, and a sense of grounded reality, it can only be achieved through supportive relationships (Gergen, 2009).

The other assumption from social constructionism particularly relevant here is: what are regarded as good reasons and good values are always within a certain tradition. Constructionism thus celebrates critical reflexivity: questioning our own assumptions, suspending the obvious, listening to various framings of realities, and grappling with the comparative outcomes of multiple standpoints. This means a relentless concern for the potential of ignoring the taken for granted. This critical reflection does not necessarily lead to a rejection of traditions; rather, it recognizes them as traditions, historically and culturally situated (Burr, 2015; Gergen, 2009). For Gergen (2009), this type of reflection is fundamental to recognizing different traditions as legitimate on their own terms.

Although what is considered to be right or wrong, is historically and culturally situated and therefore subject to transformation, it does not mean that "anything goes" (Gergen, 1985, p. 273); instead, a certain group of people hold their values and positions (Potter, 1998), and mutual exploration of different values is a way to work across conflicting realities. Knowledge and reality are human constructions, but that does not mean that one should accept any view, as clarified by Burr $(2015$, p. 107): "we have even more responsibility to think, argue, and make up our minds about our own views and them defend them". Meanings and values are to be argued, altered, defended, and invented (Edwards, Ashmore, \& Potter, 1995). From a social constructionist perspective, ethics are continuously under creation (Gergen, 2009).

\section{Ethical coaching}

"Ethics comes from the Greek word ethos, which means customs or usages, especially distinguishing one group from another" (Shapiro \& Stefkovich, 2016, p. 10). In the Aristotelian perspective, ethics is a matter of theory and praxis, since ethics inform individuals practically so they become virtuous (London, 2001). Ethics involves systematizing, defending, and recommending concepts of right and wrong behavior.

Because this research is concerned with executive coaching, an organizational development process, we consider ethics in the organizational setting. Here, ethics deals with moral principles of organizational practices in their contexts (Nielsen, 2010). According to Ghoshal (2005), management academics usually treat field-specific theories as free of morals, denying ethical considerations in management theories and therefore in management practice. In this way, people in organizations have a way of working that is constructed in relationships and interactions and considered right for that group (Burr, 2015; Gergen, 2009; Potter, 1998); moral or ethical questioning is not a part of management practice (Ghoshal, 2005).

If we question the centrality of moral aspects and ethics to executive coaching, we see that such considerations are minor, mainly not considered in coaching training programs, and most of the time limited to coaches agreeing to a code of ethics (Carroll \& Shaw, 2013; Fatien-Diochon \& Nizet, 2015; Gray, 2011). 
Despite the fact that there are coaching codes of ethics and conduct, for instance from the International Coach Federation (ICF, 2015) or the Association for Coaching and the European Mentoring and Coaching Council (AC \& EMCC, 2016), these may be considered only as starting points for ethical reflection and decision making (Fatien-Diochon \& Nizet, 2015). The issue with relying solely on codes of ethics is that the application and interpretation of such codes are left to each individual, and many ethical dilemmas are not wrong versus right, but rather right versus right. For example, a coach may need to keep a session in confidentiality while simultaneously being required to disclose that a person has harmed others (Carroll \& Shaw, 2013). In addition, these codes do not fit all situations for all practitioners (Fatien-Diochon \& Nizet, 2015).

Going beyond codes of ethics, a deeper perspective is put forth by (Carroll \& Shaw, 2013), who introduce six different components to ethical maturity, defined as

the reflective, rational, emotional and intuitive capacity to decide which actions are right or wrong, or good and better; the resilience and courage to implement those decisions; and the willingness to be accountable for ethical decisions made (publicly or privately); and the ability to learn from and live with the experience (p. 137).

Although the authors point out that ethical decisions are made in different contexts, at different times, and in different ways, they consider a sequential order in mature decision-making processes, which involves six components (Carroll \& Shaw, 2013): ethical sensitivity, the awareness of self, of harm, of impact of behavior and of intention; ethical discernment, which covers reflection, emotional awareness, problem-solving processes and decisions about the topic; ethical implementation of the decision; ethical conversation, when the decision is defended and the coach goes public, connecting the decision to his/her own principles; ethical peace, when the coach leaves with the decision, learns from the process, lets go of possible regrets, and lives with his/her own limitations; and ethical growth and development of moral character, wherein coaches use learning to enrich moral self-knowledge and to increase ethical understanding. The six components are interconnected and the process never ends, since ethical dilemmas are always new and dependent on context and the people involved. Even though personal values and cultural aspects are implicit in Carroll and Shaw's (2013) continuous path to ethical maturity, a complementary perspective that addresses how executive coaches can give ethics a priority is useful. This can be done when executive coaches take their relationships with coachees and members of the organization into consideration. I propose adapting a perspective from educational leadership, presented below, to executive coaching.

As diversity increases across the world, the educational sector faces many challenges; teaching ethics to educators calls for an inclusive, tolerant, and democratic way of perceiving students, educators and the communities they are immersed (Shapiro \& Stefkovich, 2016). Shapiro and Stefkovich (2016) introduce ethical constructs in educational leadership. Applying these to coaching is feasible, as some characteristics from educational leadership are similar to coaching. The student in education is similar to the coachee in coaching; the goal for both education and coaching is to promote a person's development. Just as in education, human interactions are key for coaching processes to progress. Formal education and coaching both target a diverse group of people. One difference between the educational sector and coaching, is that coaching is a fairly recent and unregulated activity (FatienDiochon, 2012; Western, 2012). Despite this, the abovementioned similarities are critical, which make the adaptation of a model from the educational sector applicable to executive coaching.

The ethics of the profession view presented by Shapiro and Stefkovich (2016) is a reflective and ongoing process that requires educational leaders to look at different professional codes of ethics, from different institutions, for example. It also suggests that educational leaders reflect and create their own individual codes of ethics, one personal and another professional. As this is a dynamic process, personal codes may change as the person faces different situations, reflects upon them, and makes decisions. Another aspect of Shapiro and Stefkovich's (2016) model is taking into account the wishes and circumstances of the community where education is being provided, so cultural aspects must always be considered. Inspired by the basic principles that drive medicine: do no harm, the authors believe that the moral imperative for educators is to serve the best interests of the student. The ethics of the profession 
model places the student at the center of the educator's decision-making processes, and is multidimensional and dynamic (Shapiro \& Stefkovich, 2016).

\section{Triangular relationships}

In executive coaching processes, a triangular relationship is established between the coach, the coachee, and those who pay for the service provided and represent the organization (Louis \& FatienDiochon, 2014). Included in the term organization may be the coachee's manager, Human Resources professionals involved in the process, and the coachee's subordinates and clients (de Haan, 2008a; Louis \& Fatien-Diochon, 2014; Milaré \& Yoshida, 2007; Skinner, 2012). Each of the three main stakeholders (organization, coachee, and coach) is linked to the other two in dyadic relationships: between the coach and the organization; between the coach and the coachee; and between the organization and the coachee (Louis \& Fatien-Diochon, 2014).

One relevant theme in triangular relationships in executive coaching is the presence of different agendas in these processes, and in a study with coaches, Louis and Fatien-Diochon (2014) identified ten different types of agendas in coaching processes conducted by external coaches. The study recognizes agendas initiated by the organization; the coachee; the coach; the coachee and organization together; and the coach and organization together. Among the types of agendas initiated by the organization, there is the use of coaching as a last resort, but with the decision already made to dismiss the executive, for example. Considering the types of agenda initiated by the coachee, there is the exclusion of the organization from the coaching process, as in the case when the coachee uses the coaching process to help him/her leave the company, for example. As for the agenda initiated by the coach, the authors describe that the coach may work indirectly on coaching other people in the organization in order to address the agreed-upon coaching objective of one specific coachee. Closely connected to the different agendas in executive coaching theme is the question of who the client is in such processes, discussed below.

Two relevant coaching institutions, the International Coach Federation (ICF, 2015) and the Association for Coaching and the European Mentoring and Coaching Council (AC \& EMCC, 2016), state in their code of ethics that the coaching client is the person who receives coaching, and the organization which pays the coach is the sponsor. This perspective does not present any issues if there are no competing agendas or when individual goals of the client are congruent with the organizational objectives. However, in the case of conflicts of interest between the client and the sponsor, whose interests should prevail?

There are authors who consider the organization as the client: Joo (2005) points out that clients are the organization's representatives: either HR professionals or senior executives involved in the coaching processes. In the same way, Milaré and Yoshida (2007) name the company as the client and the person receiving coaching as a participant.

Congruent with the code of ethics form the ICF (2015) and EMCC (2016), Tobias (2000) differentiates that in executive coaching, the client is the coachee, and in consulting projects, the client is the organization. Vanheule and Arnaud (2016) define the executive coaching client as the coachee because what is addressed in the coaching is the clarification of repressed aspects in the client and not the immediate achievement of management goals.

Simultaneously considering the coachee and the organization as clients, Hawkins (2008) criticizes the perspective in which the client is the coachee: for him, considering the coachee as a client means treating executive coaching similarly to therapeutic practices. Thus, when the coachee is seen as the client, there is the risk of collusion between the coach and coachee against the organization. Hawkins' (2008) recommendation is for coaches to be aware that they serve both the organization and the coachee. Similarly, Barner and Higgins (2007) and Skinner (2012) argue that if executive coaching supports people achieving organizational expectations, it is important for the coach to take into account not only the coachee's perspective, but also organizational results. The expectation that the coach perceives both 
the coach and the organization as clients may lead to the assumption that the coach is a neutral element, not favoring either the coachee's or the organization's interests.

Although some authors, such as Rocha-Pinto and Snaiderman (2011) present external coaches as "exempt, neutral individuals, without pre-judgment" (p. 563), other authors argue that executive coaches are not neutral (Critchley, 2010), impartial, or indifferent to issues of power and agendas, even if they are not conscious that they suffer such influences (Louis \& Fatien-Diochon, 2014; Skinner, 2012). In coaching processes, coachee and coach engage in a generative meaning-making process, both influenced by the other (Critchley, 2010). During coaching sessions, coachee and coach create meanings, bringing their experiences to the relationship, and both are influenced by the wider organizational context (Reissner \& Toit, 2011; Skinner, 2012). Thus, in executive coaching there are multiple layers of influences, and none of the stakeholders are neutral: neither the coach, nor the coachee, nor those who represent the organization.

Not only are participants of executive coaching processes not neutral, but identification of a single client is not completely straightforward, and triangular relationships are prone to the emergence of different agendas between stakeholders, which may lead to ethical dilemmas.

To sum up, it is valuable to consider the assumption in social constructionism that words tell the truth according to the conventions of certain groups because they work in relational rituals (Gergen, 2009) and remember that "ethos means usages belonging to one group as distinguished from another" (Shapiro \& Stefkovich, 2016, p. 10). In executive coaching, what is considered right or wrong is under construction, as everything is; ethical codes are not static laws, but changeable conventions which may work as a starting point for dialogue when stakeholders interact. The question of who the client is and the multiplicity of agendas in executive coaching are examples of potential ethical dilemmas embedded in such processes. Coaches are responsible for conducting executive coaching processes that entail triangular relationships, which may present ethical issues. How do coaches perceive triangular relationships in the coaching processes? Do they perceive possible conflicts of interest in the coaching process? If so, how do they reflect on conflicting interests? In the next section, the methodology employed to answer such questions is presented.

\section{Methodology}

A social constructionist approach is employed in this study. Methodologically, this means that the research objective is not to prove and persuade about correct interpretations, but to broaden the possibilities of understanding the phenomenon (Camargo-Borges \& Rasera, 2013). Looking at the meanings executive coaches attribute to triangular relationships, one can extend the views of understanding this phenomenon; considering if and how coaches reflect on possible conflicts of interest, one may see alternatives of reflection which can result in different courses of action.

McNamee and Hosking (2012) clarify that there is no research method that is constructional par excellence. The main question pertaining to the research strategy becomes what process to propose that allows and invites the development of meanings and production of knowledge (McNamee \& Hosking, 2012). In this study, I combine semi-structured interviews with visual data methods.

In 1991, Meyer recognized visual instruments as useful in organizational theory, specifically for research focusing on human awareness, interpretation, and consciousness. Inviting research participants to represent phenomena by drawing, or using the participant-produced drawing technique, it creates a path for the expression of emotions and helps the use of other research method in conjunction with this technique (Kearney \& Hyle, 2004).

The combination of visual data with semi-structured interviews allows researchers to look at the intersection between the emotional and the rational (Vince \& Warren, 2012), and, in this specific study, the triangular relationships in executive coaching. 
From the social constructionism perspective, the objective of the interviews is to examine how researcher and participants experience certain aspects of life as they are constructed in dialogue. In interviews conducted from the constructionist approach, the analytical and interpretative aspects develop from individual responses to the construction of meanings that occurs during the interview (Koro-Ljungberg, 2008).

The research was planned taking into consideration the information power concept (Malterud, Siersma, \& Guassora, 2016), where the aim of the research, the specificity of participants, how theory is used, the quality of dialogue, and the analysis strategy are pondered. The use of the participantproduced drawing technique combined with semi-structured interviews emphasizes the quality of the dialogue during the interview process, which is particularly important for the social constructive perspective. A thematic analysis strategy in accordance with the methodology was chosen, and participant-produced drawings were used to collect empirical data (Vince \& Warren, 2012). Since the aim of the study was to explore how executive coaches perceived triangular relationships, participants had to have experience working as external coaches. I planned to interview ten executive coaches who were identified from my personal coaching network. During one interview, we both realized that her coaching activities were more similar to internal coaching, so that data was discarded.

Research participants comprised five women and four men, ranging from 37 to 63 years of age. Three of the coaches hold a degree in Administration, three in Engineering, two in Psychology, and one in Languages. All attended at least one training coaching program, and such programs were provided by four different coaching training schools. All coaches had conducted coaching processes in organizations, working as external coaches.

The interviews were conducted using a script that served as a guide and changed twice during the research based on reflections on interactions with participants. The final interview script had three parts: first, demographic data was collected; next were descriptive questions about executive coaching; finally, coaches were asked to draw a representation of the relationship between the coachee, the organization, and the coach. The coach was then invited to explain the drawing and the participant and interviewer reflected together on the meanings of the drawing. The drawings were scanned, interviews transcribed, and most significant interview segments placed side by side with each drawing for thematic analysis. Although the interviews were longer than the segments analyzed, focusing on such excerpts is consistent with the participant-produced drawing technique and supported the thematic analyses of the drawings.

The thematic analyses were conducted in two phases: in the first step, I looked for meanings created during the interviews. In the second phase, I grouped drawings in three different categories as a way to organize the meanings created and broaden the possibilities of understanding the relationship between coachees, coaches, and organizations.

\section{Results}

After the analyses of the drawings and the content of the interviews where coaches and I talked about their illustrations, I divided the drawings into three groups: (a) coaches who do not acknowledge triangular relationship different agendas, naïve coaches; (b) coaches who rely on the process to deal with triangular relationships, procedural coaches; and (c) coaches who are skeptical when dealing with triangular relationships, suspicious coaches. I present drawings and interview excerpts from the first group in Table 1 and elaborate on its content below. 
Table 1

\section{Naïve Coaches}

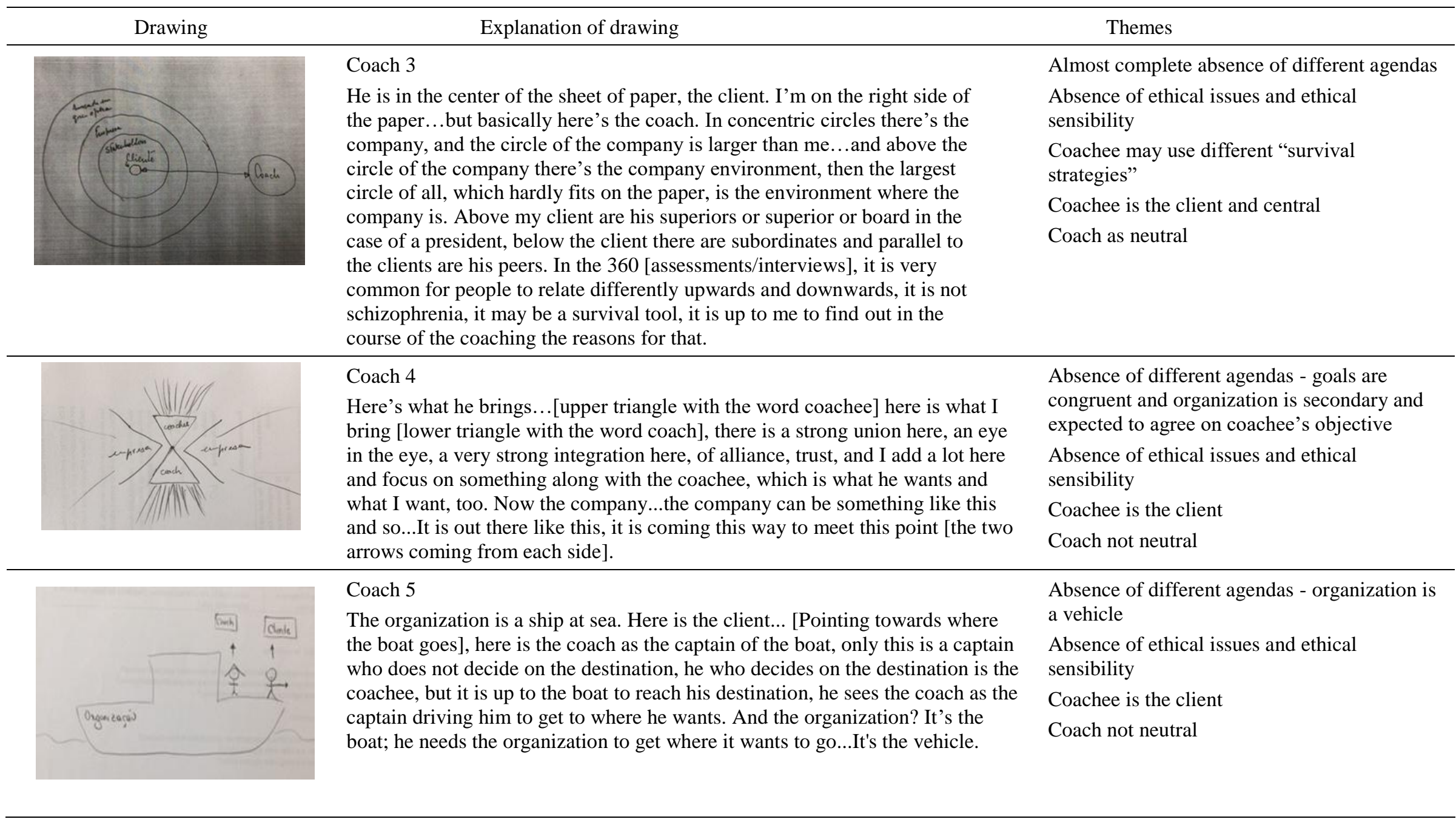

Note. The author has obtained permission from the participants to reproduce these drawings.

BAR, Rio de Janeiro, v. 14, n. 4, art. 4, e170050, 2017 
There are three coaches in this group. Coaches 4 and 5 portray relationships between coachee, coach, and organization as harmonious and coherent, with no representation of different agendas. This is also the case of coach 3, who drew different stakeholders and mentioned only the possibility of the coachee relating differently to his/her bosses and subordinates, which could be seen as different agendas. Because this possible agenda does not include the coach, I integrated coach 3 in this group. Also, like coaches 4 and 5, coach 3 does not make reference to any ethical aspect of the coaching process.

Considering neutrality, on one hand, coaches 4 and 5 refer to the coach as not neutral: coach 4 says he adds a lot to the process and what the clients want he also wants; coach 5 draws the coach as the captain of the boat, although one who does not set the boat's destination. In both cases, the coach is portrayed as inside the system, with a role, in the case of the captain, or desire, in the case of coach 4 wanting to help the coachee. On the other hand, coach 3 can be perceived as neutral, outside of the system and with only an arrow linking him to the client.

The main reasons for grouping these coaches together are the absence of ethical issues among the themes in the drawings and interviews. As can be seen in Tables 2 and 3, ethics in executive coaching are portrayed in these groups. 
Table 2

\section{Procedural Coaches}

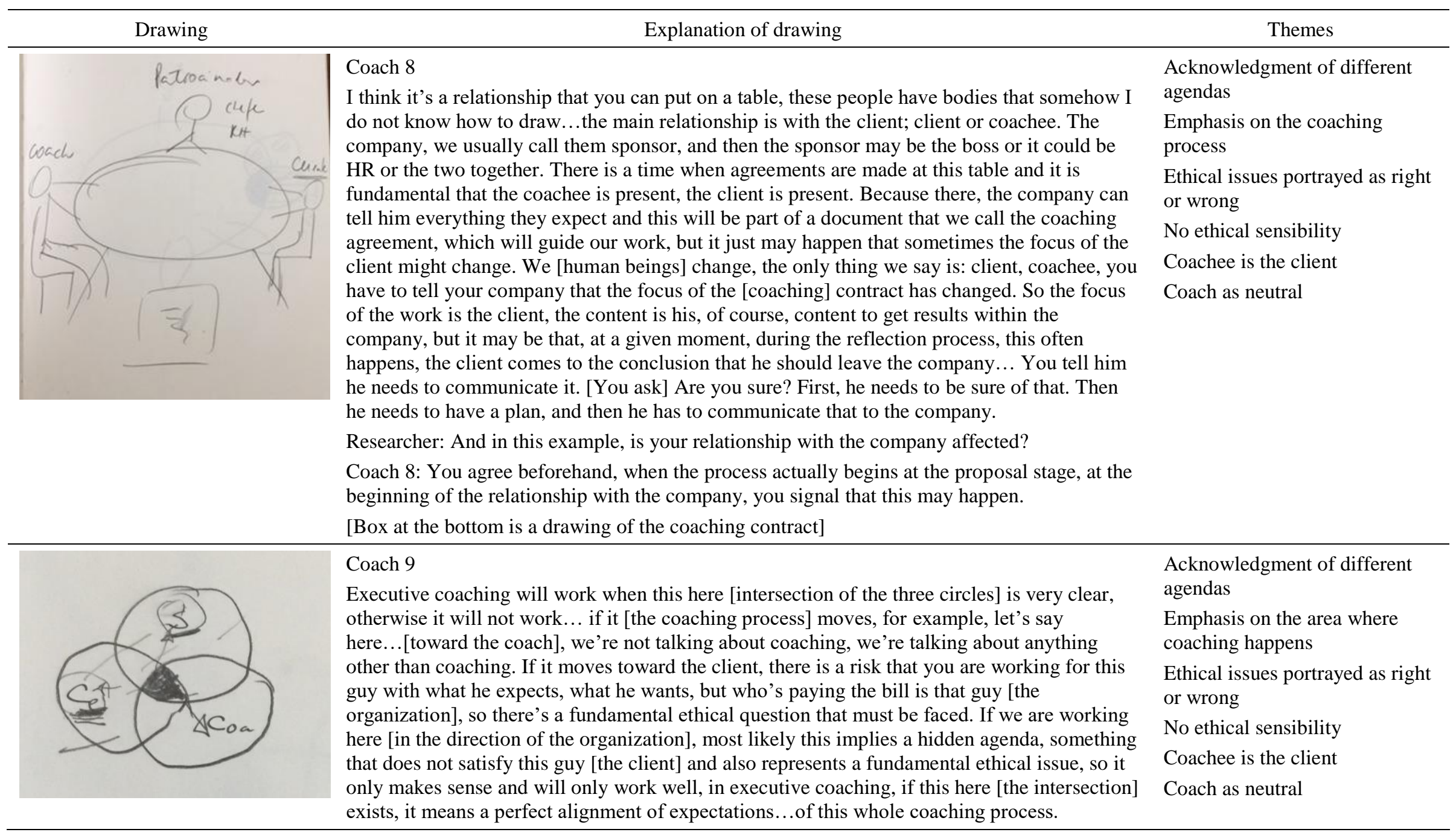

Note. The author has obtained permission from the participants to reproduce these drawings.

BAR, Rio de Janeiro, v. 14, n. 4, art. 4, e170050, 2017 
Table 3

\section{Suspicious Coaches}

\begin{tabular}{|c|c|c|}
\hline Drawing & Explanation of drawing & Themes \\
\hline Coadree (Avinte) & $\begin{array}{l}\text { Coach } 1 \\
\text { The coach is there as a facilitator, the company-plays the role of a supporter of the } \\
\text { development process, and the coachee is the client as well as the person who will } \\
\text { have the opportunity to take advantage of that investment, so that's why I drew it } \\
\text { right here [at the top of the triangle]. [The coachee] is the main focus, the } \\
\text { company would be the focus, let's say, the one who will reap the coachee's } \\
\text { development results. } \\
\text { Researcher: And in the event of a conflict of interests? } \\
\text { That's a bomb that can go off in any corporate process and I reluctantly went to } \\
\text { work for corporations...I do not want to work for the company, I want to work for } \\
\text { the person...I want to develop the person... The corporate market is closer to me } \\
\text { today and the financial return is faster, until I mature and see what the } \\
\text { possibilities are for marketing my work to more individuals. }\end{array}$ & $\begin{array}{l}\text { Acknowledgment of different agendas } \\
\text { Ethical issues portrayed as dilemmas } \\
\text { Ethical sensitivity: awareness but lack of tools } \\
\text { on how to deal with dilemmas } \\
\text { Coachee is the client } \\
\text { Coach not neutral - how he/she feels towards } \\
\text { the dilemmas and acknowledgment of personal } \\
\text { preference }\end{array}$ \\
\hline & $\begin{array}{l}\text { Coach } 2 \\
\text { The individual is inside the company. I'm here in the company too, because I } \\
\text { have guidelines, I have the relationship with HR and so forth. That is me } \\
\text { [pointing to the circle "Eo"]. The Coachee is inside the company, obviously... } \\
\text { Here he is [the client] as a whole person, he as a person and such, this is his side } \\
\text { in the organization...mine is another relationship with the company. } \\
\text { Researcher: Can you comment on the size of the company? } \\
\text { I have other situations that replicate with other coachees. It just seems like the } \\
\text { company is a huge thing for this coachee, but it's because it has ... of course, it's } \\
\text { him inside the company. } \\
\text { [two elliptical forms at the bottom are a representation of other coachees] }\end{array}$ & $\begin{array}{l}\text { Acknowledgment of different agendas } \\
\text { Ethical issues portrayed as dilemma } \\
\text { Ethical sensitivity: Possible dilemmas, for } \\
\text { example with other coachees } \\
\text { Not clear who the client is } \\
\text { Coach not neutral - whole person, with } \\
\text { guidelines, may be influenced by other people }\end{array}$ \\
\hline
\end{tabular}

Continues 


\section{Table 3 (continued)}

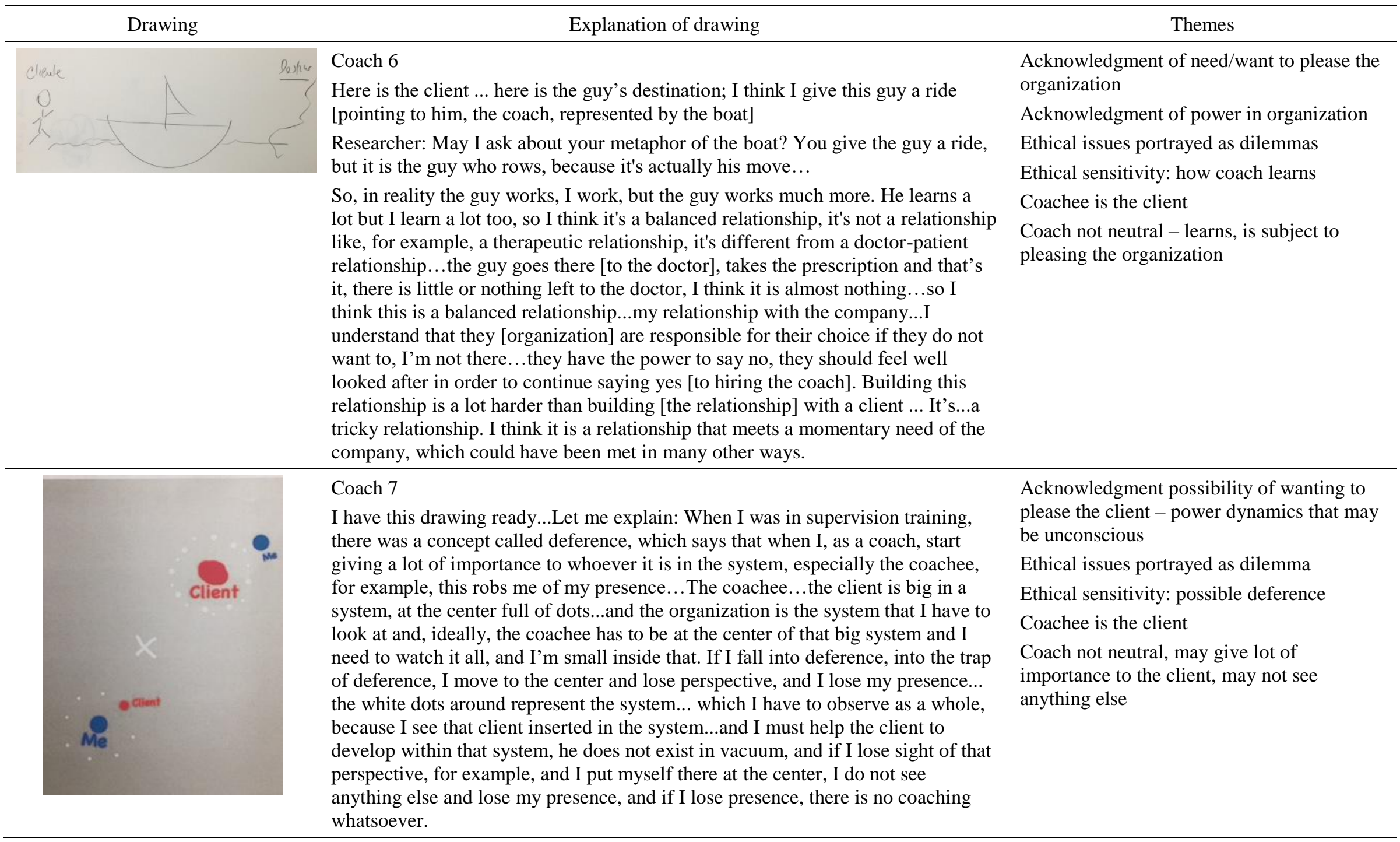

Note. The author has obtained permission from the participants to reproduce these drawings.

BAR, Rio de Janeiro, v. 14, n. 4, art. 4, e170050, 2017 
Coaches 8 and 9, from group 2, acknowledge different agendas in the executive coaching process: coach 8 comments that there is a possibility of the coachee wanting to resign from the company and coach 9 mentions that the coach works for the coachee but that the organization pays the bill. She also considers hidden agendas that may exist between the coach and the organization. Ethical issues are perceived as right or wrong, and there is a prescriptive tone to deal with such issues: for coach 8 , the emphasis is on the coaching contract, and for coach 9, there is a specific area where executive coaching happens. Both coaches represent the coach as neutral: coach 9 describes how the coaching process may move toward different stakeholders, but does not consider what such movements mean for the coach; for coach 8 the role of the coach seems to be of a neutral mediator between the coachee's objectives and how the organization should reap the results of the process.

Among other differences, coaches in group 3 do not see themselves as neutral, as can be seen in Table 3.

Drawings in group 3 acknowledge different agendas in executive coaching and with this, possible dilemmas: coach 1 mentions his problem in reconciling the coachee's objectives with the company's and his preference in working with individuals; coach 2 refers to HR's policies she has to follow and other coachees' interests, which she may have to manage; coach 6 comments on the power the organization has to hire and fire external coaches and difficulties pleasing the organization; and coach 7 brings up deference, which may interfere in the coaching process because of unconscious dynamics and the risk of losing his presence and jeopardizing the coaching dynamic. Coaches in group 3, like group 2, perceive different agendas in the triangular relationships in executive coaching; the difference from the previous group is that the issues these agendas bring are not perceived as right or wrong, but rather as dilemmas.

Another prevailing feature of drawings and interview quotes in group 3 is how coaches see themselves as not neutral: coach 1 clearly shares how he feels towards possible conflict of interest between the organization and the coachee, and acknowledges his personal preference. Coach 2 perceives himself and the coachees as whole people, with lives outside the company, besides the aforementioned influences he may receive. Coach 6 shares that she learns in the relationships with coaches, and coach 7 how he may desire to impress the coachee and, because of this, may not see other aspects of the coaching process. Coaches in this group see themselves as part of the system and note how the system may affect them and, for coach 7 , how their feelings may affect the coaching process. These coaches may be seen as skeptical of taken-for-granted congruent coaching objectives and suspicious that coaching processes are power free.

The prevailing themes used to form the groups were the perception of triangular relationships and how coaches reflected on conflict of interests. The issue of conflict of interest between the coachee and the organization may be closely linked with who the coach considers as his/her client. The client is the coachee for coaches in all three groups: coaches 3 and 5, from group 1, make that explicit, as do coaches 6 and 7 from group 2 and coaches 6 and 7 from group 3. There are coaches in group 1 and 3 who do not clarify who the client is. Coaches in group 1 name the coachee as the client and may expect that to be understood by all involved. Coaches in group 2 name the coachee as the client and rely on the coaching process and contract to clarify the concept. Coaches in group 3 perceive conflicts of interests in coaching processes go beyond naming who the client is and the coaching process and contract.

\section{Discussion}

Coaches have different perceptions regarding triangular relationships in executive coaching: for some, such relationships are harmonious and present no issues, for others there might be conflicts of interest. For coaches who are aware of conflicts of interests, the way external coaches deal with them varies: some are process driven and others are more skeptical. The empirical material suggests there is 
an opportunity for coaches to use a perspective which puts the coachee at the center of the coaching process, offers an integrative model, and prompts coaches to critical reflection. Such a perspective can be useful to the practice and theory of coaching and is adapted from the ethics of the profession view proposed by Shapiro and Stefkovich (2016), as will be presented below.

Coaches differ regarding how they perceive triangular relationships in executive coaching: some coaches do not sense different agendas in executive coaching (group 1). Coaches in group 2 or 3 refer to different agendas in executive coaching, and some of these agendas had been described by Louis and Fatien-Diochon (2014): an agenda initiated by the coachee excluding the organization from the process is mentioned by coach 8 . Coach 2 mentions how he may have to manage different coachees in the same organization. In this case, if the coach does not handle processes with different coachees well, this could lead to the coach's hidden intervention strategy as described by Louis and Fatien-Diochon (2014). Other coaches, like coaches 9, 1, and 7 acknowledge the existence of different agendas but are not specific on who may initiate them. Power dynamics present in coaching processes (Fatien-Diochon, 2012; FatienDiochon \& Nizet, 2015; Skinner, 2012) were explicitly mentioned by coaches 2 and 6, specifically the need to follow HR directions as this area is perceived as having the power to hire and fire external coaches. Thus, there are coaches who view executive coaching as a harmonious and congruent process, group 1, naive coaches; and those who acknowledge different agendas may be present, groups 2 and 3. What separates coaches from groups 2 and 3 are the ways they reflect on possible conflicts of interest in executive coaching.

When it comes to those conflicts of interests, although coaches in group 2 refer to ethical issues and conflicts of interest in executive coaching, in their case, ethics in coaching are portrayed rigidly. For example, coach 9 affirms that coaching only happens if all stakeholders are in agreement. This may be the result of relying on a formal code of ethics, which could lead to the prescriptive tone and right or wrong approach to ethics from coaches in this group. Formal codes are essential to the practice of coaching, but not enough to encompass all situations and possible ethical dilemmas (Fatien-Diochon \& Nizet, 2015; Gray, 2011). In addition, such codes do not necessarily foster ethical sensitivity, defined by Carroll and Shaw (2013) as the awareness of self, of harm, of impact of behavior, and of intention. Ethical sensitivity refers to the coach reflecting on him/herself and how the practice may impact and hurt others. Ethical sensitivity thus implies an understanding that the coach is not neutral and consideration that the practice of coaching is not moral free. The line of thinking showed in group 2, coaches might show the influence of management theories in coaching (Western, 2012), which enables the perception of coaching as a moral-free activity, as many management practices are considered (Ghoshal, 2005). From this perspective, it may be harder for coaches to show ethical sensitivity if they perceive themselves as neutral.

The concepts of the coach not being neutral and ethical sensitivity can be connected to the empirical material from group 3: these coaches do not portray themselves as neutral; they are part of the dynamic in the coaching process as they show their preferences, skepticism, and desire to please stakeholders, and point out different power forces in the system. From the not-neutral position, these coaches are able to show awareness of their own impact on the coaching process; they are thus, more able to show ethical sensitivity. Moreover, coaches in group 3 may move in the direction of moral discernment, the second component of Carroll and Shaw's (2013) perspective, since they show reflection and emotional awareness. The drawings do not show problem solving or decision about the topic, though.

The issue of the coach being neutral is closely connected with the question of who the client is in executive coaching. This question forces a choice for the coach among three options: the client may be coachee; the client may be the organization; or the client can be both organization and coachee. If the client is the coachee, as recognized by the ICF (2015) and EMCC (2016), then there is the risk of exclusion of the organization's, or sponsor's, interest in the process (Hawkins, 2008). If the organization is perceived as the client, as suggested by some authors like Joo (2005) and Milaré and Yoshida (2007), then there is a risk of damaging the trust between the coachee and the coach, and without trust, the relationship is broken and the coaching process probably will not happen (de Haan, 2008b). If the coach considers the coachee and the organization as clients, as suggested by Hawkins (2008), then the coach 
is expected to mediate the needs of the organization and the coachee, and there might be an emphasis on the neutrality of the coach. As seen above, the perception of a coach being neutral may not encourage ethical sensibility since the coach has little awareness of self and their own impact in the coaching process. A more generative approach to looking at the different stakeholders' relationships in executive coaching may be borrowed from the educational sector, where different perspectives are taken into consideration and there is no expectation of neutrality.

Figure 1 shows the ethics of the profession diagram, developed by Shapiro and Stefkovich (2016). The left-hand side of the figure represents their perspective, which can be adapted to executive coaching (right-hand side of Figure 1) as a way to foster critical reflection and ethical maturity among executive coaches.

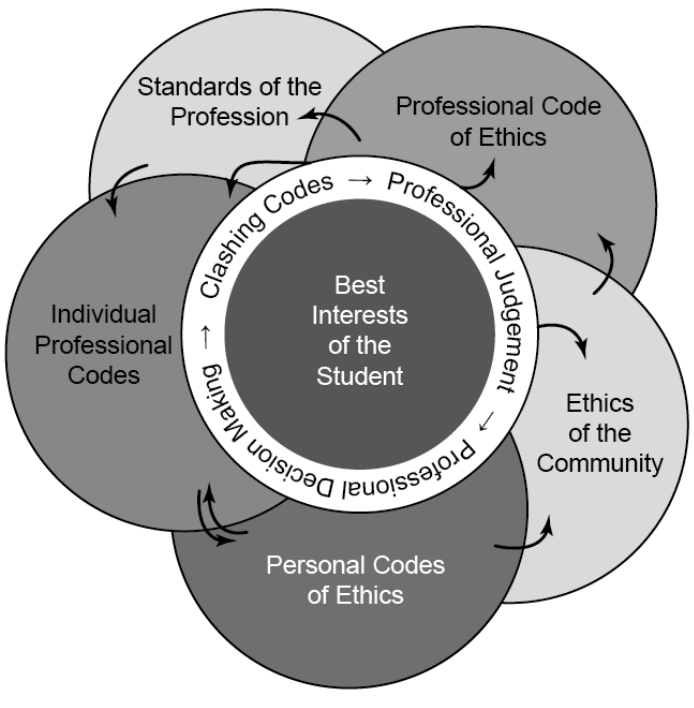

Ethics of the Profession from Shapiro and Stefkovich

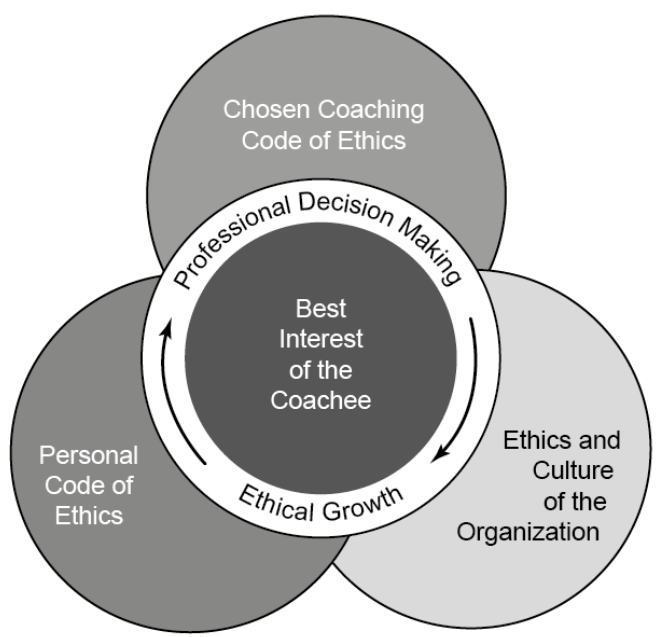

Adaptation to Executive Coaching

Figure 1. Adaptation of the Ethics Professional Paradigm from Educational Leadership to Executive Coaching

Source left diagram: Shapiro, J. P., \& Stefkovich, J. A. (2016). Ethical leadership and decision making in education: Applying theoretical perspectives to complex dilemmas (4th ed.). (p. 26). New York, NY: Routledge. Reproduced with permission of the authors. Source right diagram: adaptation made by the author.

The ethics of the profession perspective does not consider educational professionals as neutral, since one component of the model is the presence of a personal code of ethics. The personal code of ethics, as described by Shapiro and Stefkovich (2016), encourages educators to be conscious of their personal values. Educators write their individual codes taking into consideration their life stories and experiences. In the adapted model for coaches, the personal code of ethics is maintained; coaches are invited to write their individual personal code of ethics, based on their experiences, life stories, and personal values.

The central element in the diagram of the ethics of the profession is the best interests of the student, conceptualized as interests incorporating individual rights; accepting and teaching students to accept responsibility for one's actions; and respecting students (Shapiro \& Stefkovich, 2016). This concept is congruent with the centrality coachees have in executive coaching processes: the empirical material shows that independently of the group, coaches place the coachee as a central figure in the coaching process. In addition, placing the coachee in the center of the process may be a more generative way of considering different stakeholders and goes beyond naming the coachee as client and the organization as sponsor. 
In the ethics of the profession perspective, one element is the ethics of the community where educators are invited to consider that student populations, parents, and communities are comprised of many diverse categories of race, ethnicity, religion, social class, gender, disability, and sexual orientation, for example (Shapiro \& Stefkovich, 2016). This element implies considering and respecting the context of the present and past circumstances of students and educators, taking into account the lenses through which they see the world. This element can be adapted to executive coaching, as coaches consider the context where executives work and how people make decisions inside that specific organization. This reflects the criticality of the context where stakeholders are immersed.

In the U.S., different educational professional associations and states have their professional codes of ethics, which should serve as guideposts for the educational professions (Shapiro \& Stefkovich, 2016). These formal professional codes of ethics parallel coaching codes of ethics from different coaching organizations such as the ICF and EMCC or coaching training programs like Ashridge Code of Conduct for Coaches (2016). Considered guideposts, such codes of ethics are not expected to fit all situations and provide answers to all ethical dilemmas, but they are important starting points for reflection and ethical decision making (Fatien-Diochon \& Nizet, 2015; Gray, 2011). This way, in the adapted model of the ethics of the profession, coaches are encouraged to elect one formal code of ethics and consider it a relevant perspective when making professional decisions.

In Shapiro and Stefkovich's (2016) model, three aspects surround the student's best interests: clashing codes, professional judgment, and professional decision-making. This area highlights how ethical codes may conflict: for example, a professional code of ethics may differ from a personal code of ethics; or if a person has two professions, the two professional codes may clash. Clashing codes bring up ethical dilemmas educators may face, and influence the educator's judgment and decision-making in a specific situation. In short, the circle surrounding the student's best interests refers to actions taken by educators facing an ethical dilemma.

In the adapted version of this model, there is the opportunity to incorporate Carroll and Shaw's (2013) ethical maturity concept, which includes the reflective, rational, emotional, and intuitive ability the coach has to decide on a course of action before an ethical dilemma; his/her resolution to apply the decision; being accountable for the decision made and implemented; and learning from the episode. Ethical maturity, as defined earlier, is the means through which the executive coach makes his/her professional decision and allows for ethical growth, in a continuous process. Ethical maturity is then, the process in the middle of the model on the left-hand side of Figure 1, that allows for professional decision making and ethical growth for coaches. This process keeps the best interests of the coachee central and has as a background the coach's personal code of ethics, the chosen code of ethics, and the organization's values.

One can note in Figure 1 two areas not included in the adapted model: standards of the profession, and individual professional codes. Because coaching is a rather recent development and still not regulated (Western, 2012), there are no formal professional standards, so this element has been excluded from the adapted model. Regarding individual professional codes, Shapiro and Stefkovich (2016) suggest that educational leaders write individual codes of ethics relating to their activities in the educational field. Today, elaborating such a code may be more relevant to educators than it is for coaches: the empirical material in this study shows that coaches may not be aware of ethical issues in the field and even when they are aware, some coaches perceive ethics more as right or wrong issues than as dilemmas. On top of this, the coaching literature highlights ethics as a theme peripheral to practice (Fatien-Diochon \& Nizet, 2015; Gray, 2011). These two aspects, lack of awareness among coaches on ethical dilemmas and the distance from ethical issues present in the practice of coaching, guided the decision to exclude the individual professional code from the model, at least for now. As the field of coaching develops, the incorporation of this element may be revisited.

Shapiro and Stefkovich's (2016) adapted perspective emphasizes how the coach relates to different elements in the coaching process: first, it makes the centrality and importance of the coachee explicit and, at the same time, how the coach relates to the formal code ethics, to his/her personal values, and to what is important to the organization. In this way, the coach may make sense of different 
meanings pertinent to each of these relationships. Such a perspective is congruent with the centrality of relationships in social constructionism, since our understandings about the world are reached through coordination between people, such as with compared visions, for example (Gergen, 2009). The model also makes room for critical reflexivity, as it invites coaches to suspend what might be considered obvious from any stakeholder's point of view and listen to viewpoints of different framing realities.

\section{Final Considerations}

Taking a social constructionist theoretical and methodological perspective, the research presented in this article expands the options of understanding triangular relationships in executive coaching: such relationships may be perceived by naïve coaches as placid and straightforward processes with congruent objectives between the coachee, the coach, and the organization. These relationships may also be seen as prone to conflicting interests and ethical dilemmas. The ways coaches deal with conflicting interests in triangular relationships vary: procedural coaches take a prescriptive approach and rely on the coach's neutrality, coaching contract, and coaching process to deal with ethical issues, which are perceived as right or wrong. Other coaches, suspicious ones, deal with conflicting interests by taking a skeptical look at the sufficiency of coaching contracts. They see themselves as part of the process they manage, and express feelings and doubts. Such coaches show ethical sensitivity, a first step to ethical maturity. The three categories suggested in the article, naïve, procedural and suspicious coaches, may be considered as open, meaning that the same coach might float between them during a coaching engagement. For example: when invited to conduct a coaching engagement, the coach may be hopeful that objectives between stakeholders will align (group 1, naïve coaches). Later, the coach might want to make sure stakeholders roles are clarified (group 2, procedural coaches), and at any point in the process, the coach might perceive different agendas in the process and reflect on how they affect him/her (group 3, suspicious coaches).

Besides expanding the options of understanding triangular relationships, this article also proposes a model for coaches to deal with ethical dilemmas in executive coaching. Such model takes into account the centrality of the coachee as the main stakeholder in the executive coaching process and at the same time considers the coach's personal values, the culture and context of the organization. The proposed model integrates the three stakeholders' interests and a formal coaching code of ethics via the ethical maturity reflective perspective by Carroll and Shaw (2013).

It is key to mention the adapted model limitations: the original perspective from Shapiro and Stefkovich (2016) was developed for the educational sector to be used during courses of ethics in education and it is important that authors in coaching literature and practitioners are aware of the origins and context of the original perspective.

Also, the empirical material could be enriched if the themes and meanings attributed to the drawings had been discussed, after the analyses, with the participants. This was not done due to time and access constraints. Another limitation is that the study took into consideration only the coach's perspective. Although coaches, being responsible for conducting the process, justify the importance of their perspective, having the coachees' and the organizations' views can expand the opportunities for further understanding of triangular relationships in executive coaching. Finally, there are coaching firms who work as intermediates between the organization who hires the coaching services and external coaches. Such firms add another level of complexity to executive coaching, and were not considered in this article.

There is opportunity for future research to explore how coachees and people who represent the organization perceive triangular relationships in executive coaching. In addition, researching other stakeholders such as coaching firms and coaching training programs, can expand the options of further understanding executive coaching, a relevant and ubiquitous organizational development process. 


\section{References}

Ashridge Executive Education. (2016). Ashridge code of conduct for coaches. Retrieved September 18, 2017 from http://www.thecoachingconnection.com/wp-content/uploads/2017/03/CoachingCode-of-Conduct.pdf

Association for Coaching \& European Mentoring \& Coaching Council. (2016). Global code of ethics for coaches \& mentors. Retrieved September 7, 2017, from http://www.emccouncil.org/src/ultimo/models/Download/4.pdf

Barner, R., \& Higgins, J. (2007). Understanding implicit models that guide coaching process. Journal Management Development, 26(2), 148-158. https://doi.org/10.1108/02621710710726053

Berger, P., \& Luckmann, T. (2002). A construção social da realidade (22a ed.). Petrópolis: Vozes.

Bluckert, P. (2006). Psychological dimensions of executive coaching. Maidenhead: McGraw-Hill Education.

Bozer, G., Sarros, J. C., \& Santora, J. C. (2014). Academic background and credibility in executive coaching effectiveness. Personnel Review, 43(6), 881-897. https://doi.org/10.1108/PR-10-20130171

Burr, V. (2015). Social constructionism (3rd ed.). Hove: Routledge.

Camargo-Borges, C., \& Rasera, E. F. (2013). Social constructionism in the context of organization development: Dialogue, imagination, and co-creation as resources of change. SAGE Open, 3(2), 2158244013487540. https://doi.org/10.1177/2158244013487540

Carroll, M., \& Shaw, E. (2013). Ethical maturity in the helping professions: Making difficult life and work decisions. London: Jessica Kingsley Publishers.

Critchley, B. (2010). Relational coaching: Taking the coaching high road. Journal of Management Development, 29(10), 851-863. https://doi.org/10.1108/02621711011084187

Cunliffe, A. L. (2008). Orientations to social constructionism: Relationally responsive social $\begin{array}{llll}\text { constructionism. Management } & \text { Learning, } & \text { 39(2), } & \text { 123-139. }\end{array}$ https://doi.org/10.1177/1350507607087578

de Haan, E. (2008a). I struggle and emerge: Critical moments of experienced coaches. Consulting Psychology Journal: Practice \& Research, 60(1), 106-131. https://doi.org/10.1037/10659293.60.1.106

de Haan, E. (2008b). Relational coaching: Journeys towards mastering one-to-one learning. West Sussex: John Wiley \& Sons.

de Haan, E., Duckworth, A., Birch, D., \& Jones, C. (2013). Executive coaching outcome research: The contribution of common factors such as relationship, personality match, and self-efficacy. Consulting Psychology Journal: Practice and Research, 65(1), 40-57. https://doi.org/10.1037/a0031635

Duffy, M., \& Passmore, J. (2010). Ethics in coaching: An ethical decision making framework for coaching psychologists. International Coaching Psychology Review, 5(2), 140-151.

Edwards, D., Ashmore, M., \& Potter, J. (1995). Death and furniture: The rhetoric, politics and theology of bottom line arguments against relativism. History of the Human Sciences, 8(2), 25-49. https://doi.org/10.1177/095269519500800202 
Fatien-Diochon, P. (2012). Ethical challenges in business coaching. In M. Smith \& M. Esposito (Eds.), Business ethics: A critical approach integrating ethics across the business world (pp. 302-316). London: Routledge.

Fatien-Diochon, P., \& Nizet, J. (2015). Ethical codes and executive coaches: One size does not fit all. The Journal of Applied Behavioral Science, 51(2), 277-301. https://doi.org/10.1177/0021886315576190

Feldman, D. C., \& Lankau, M. J. (2005). Executive coaching: A review and agenda for future research. Journal of Management, 31(6), 829-848. https://doi.org/10.1177/0149206305279599

Gergen, K. J. (1985). The social constructionist movement in modern psychology. American Psychologist, 40(3), 266-275. https://doi.org/10.1037/0003-066X.40.3.266

Gergen, K. J. (2009). An invitation to social construction (2nd ed.). London: Sage.

Ghoshal, S. (2005). Bad management theories are destroying good management practices. Academy of Management Learning \& Education, 4(1), 75-91. https://doi.org/10.1109/EMR.2005.26768

Grant, A. M. (2014). The efficacy of executive coaching in times of organizational change. Journal of Change Management, 14(2), 258-280. https://doi.org/10.1080/14697017.2013.805159

Gray, D. E. (2011). Journeys towards the professionalisation of coaching: Dilemmas, dialogues and decisions along the global pathway. Coaching: An International Journal of Theory, Research and Practice, 4(1), 4-19. https://doi.org/10.1080/17521882.2010.550896

Hawkins, P. (2008). The coaching profession: Some of the key challenges. Coaching: An International Journal of Theory, Research and Practice, 1(1), 28-38. https://doi.org/10.1080/17521880701878174

Hepburn, A., \& Wiggins, S. (2005). Discourse and society. Discourse and Society, 16(5), 625-645. https://doi.org/0957926505054939

International Coach Federation. (2015, June). Code of ethics. Retrieved September 7, 2017, from https://www.coachfederation.org/about/landing.cfm?ItemNumber=854\&navItemNumber=634

International Coach Federation. (2016). 2016 ICF global coaching study. Retrieved from https://coachfederation.org/about/landing.cfm?ItemNumber=3936\&_ga=2.101611333.5932492 28.1512260835-1078803662.1407631290

Joo, B.-K. (Brian). (2005). Executive coaching: A conceptual framework from an integrative review of practice and research. Human Resource Development Review, 4(4), 462-488. https://doi.org/10.1177/1534484305280866

Kearney, K. S., \& Hyle, A. E. (2004). Drawing out emotions: The use of participant-produced drawings in qualitative inquiry. Qualitative Research, 4(3), 361-382. https://doi.org/10.1177/1468794104047234

Koro-Ljungberg, M. (2008). A social constructionist framing of the research interview. In J. A. Holstein \& J. F. Gubrium (Eds.), Hanbook of contructionist research (pp. 429-444). New York: The Guilford Press.

London, A. J. (2001). Moral knowledge and the acquisition of virtue in Aristotele's Nicomachean and Eudemian ethics. The Review of Metaphysics, 54, 553-583. Retrieved from http://www.jstor.org/stable/20131576?seq=1\#page_scan_tab_contents 
Louis, D., \& Fatien-Diochon, P. (2014). Educating coaches to power dynamics: Managing multiple agendas within the triangular relationship. Journal of Psychological Issues in Organizational Culture, 5(2), 31-47. https://doi.org/10.1002/jpoc.21140

Malterud, K., Siersma, V. D., \& Guassora, A. D. (2016). Sample size in qualitative interview studies. Qualitative Health Research, 26(13), 1753-1760. https://doi.org/10.1177/1049732315617444

McNamee, S., \& Hosking, D.-M. (2012). Research and social change: A relational constructionist approach. New York: Routledge.

Meyer, A. D. (1991). Visual data in organizational research. Organization Science, 2(2), 218-236. https://doi.org/10.1287/orsc.2.2.218

Milaré, S. A., \& Yoshida, E. M. P. (2007). Coaching de executivos: adaptação e estágio de mudanças. Psicologia: Teoria e Prática, 9(1), 86-99. Retrieved from http://editorarevistas.mackenzie.br/index.php/ptp/article/view/682/401

Nielsen, R. P. (2010). Practitioner-based theory building in organizational ethics. Journal of Business Ethics, 93(3), 401-406. https://doi.org/10.1007/s10551-009-0229-3

Potter, J. (1998). Fragments in the realization of relativism. In I. Parker (Ed.), Social constructionism, discourse and realism (Inquiries in social construction series) (pp. 27-46). London: Sage.

Reissner, S. (2008). Narrative \& storytelling: New perspectives on coaching. International Journal of Mentoring and Coaching, 6(3), 1-9.

Reissner, S. C., \& Toit, A. du (2011). Power and the tale: Coaching as storyselling. The Journal of Management Development, 30(3), 247-259. https://doi.org/10.1108/02621711111116171

Rocha-Pinto, S. R. da, \& Snaiderman, B. (2011, novembro). A contribuição do coaching executivo para o aprendizado individual: a percepção dos executivos. Anais do Encontro de Gestão de Pessoas e Relações de Trabalho, João Pessoa, PB, Brasil, 3.

Shapiro, J. P., \& Stefkovich, J. A. (2016). Ethical leadership and decision making in education: Applying theoretical perspectives to complex dilemmas (4th ed.). New York: Routledge. https://doi.org/10.4324/9781315773339

Sherman, S., \& Freas, A. (2004). The wild west of executive coaching. Harvard Business Review, 82(11), 82-93. Retrieved from https://hbr.org/2004/11/the-wild-west-of-executive-coaching

Skinner, D. (2012). Outside forces in the coaching room: How to work with multiparty contracts. In E. de Haan \& C. Sills (Eds.), Coaching relationships: The relational coaching field book (Kindle ed., pp. 111-124). Oxfordshire: Libri Publishing.

Stelter, R. (2009). Coaching as a reflective space in a society of growing diversity - towards a narrative, postmodern paradigm. International Coaching Psychology Review, 4(2), 207-217. https://doi.org/2013/187365

Stern, L. R. (2004). Executive coaching: A working definition. Consulting Psychology Journal: Practice and Research, 56(3), 154-162. https://doi.org/10.1037/1065-9293.56.3.0

Tobias, L. L. (2000). Coaching executives. Consulting Psychology Journal: Practice and Research, 48(2), 87-95. https://doi.org/10.1037/1061-4087.48.2.87

Vanheule, S., \& Arnaud, G. (2016). Working with symbolic transference: A Lacanian perspective on executive coaching. The Journal of Applied Behavioral Science, 52(3), 296-319. https://doi.org/10.1177/0021886316654764 
Vince, R., \& Warren, S. (2012). Participatory visual methods. In C. Cassell \& S. Gillian (Eds.), The practice of qualitative organizational research: Core methods and current challenges (pp. 275298). London: Sage. https://doi.org/10.1017/CBO9781107415324.004

Western, S. (2012). Coaching and mentoring: A critical text. London: Sage.

\section{Author's Profile}

Ana Pliopas

Rua Itapeva, 474, 01313-902, São Paulo, SP, Brazil. E-mail address: analuisavieira@uol.com.br 